\title{
COUNTRY FUNDAMENTALS AS A FORM OF MARKET SELF-REFERENTIALITY
}

\author{
Sascha Engel \\ Department of Political Science Virginia Tech, USA
}

\begin{abstract}
The origin of the Eurozone crisis lies neither in unsustainable borrowing nor in arbitrary demands of creditors. Rather, its origin lies in the effects of seemingly arcane technicalities to which sovereign debt issuance is subject. To show this, this paper proposes a set of terms equipped to analyze the effects of these minuscule technicalities. The notion of country fundamentals could be replaced with that of a fundamental to show that a country is not subject to market assessment when borrowing, but rather subject to market lending pressures forcing it to adopt certain policies even in the absence of outright imposition. Moreover, the paper argues for the notions of flow-stock conversion and liquidity-solvency conversion. The former allows the conversion of sovereign debt as a fiscal instrument to sovereign debt as an asset, thus embedding it into sovereign debt market dynamics. These, in turn, play out as pressure upon the country through the liquidity-solvency conversion turning portfolio restructurings into fiscal solvency shortages. Finally, the paper analyzes countries as intra-market hedges and extra-market hedges to illustrate the extent of market pressures upon countries: to recapitalize banks, countries need to issue more debt, doubling down on the pressure from the liquidity-solvency conversion.
\end{abstract}

Keywords: Country Fundamentals; Eurozone Crisis; Flow-Stock Conversion; Liquidity-Solvency Conversion; Sovereign Debt and Sovereignty 


\section{Introduction}

With the recent troubles facing Greece, threatening its membership in the Eurozone, it has come to be reinforced that the Eurozone crisis is here to stay (Wearden and Fletcher 2015). To most, the origin and duration of the crisis are explained by the recklessness of European peripheral governments - particularly Greece - whose unwillingness to reform, sustained prior to 2009 by a corresponding market willingness to lend regardless, has now come to threaten to structural integrity of the Eurozone itself (ECB 2010; Belke 2011). Others have criticized this approach, arguing that the Eurozone crisis is a crisis of growth, originating on bank balance sheets and protracted by austerity (Shambaugh 2012; Blyth 2015).

This paper positions itself between the two approaches, albeit closer to the latter. I argue that the origin of the Eurozone crises lies neither in governments' fiscal practices as such, nor in deliberate actions of European banks. Sweeping claims from both sides - morally pernicious recklessness of Southern European governments; a 'bait-and-switch' by the European banking system (Blyth 2015: 73) - are equally problematic. I maintain that a nuanced and precise discussion of the political effects contained in sovereign debt technicalities exposes more about the origins of the Eurozone crisis than sweeping claims from either side.

By the same token, I propose in this paper a terminology which I maintain is better equipped than that of critical or mainstream views on the crisis to expose the minuscule power effects contained in sovereign debt technicalities. These create a political dynamic to which both creditors and debtors are subject - though the latter, to be sure, to a more substantial extent. The given terminology of studies on sovereign debt ('moral hazard', 'contagion', 'time horizons', 'fundamentals', and so forth) cannot be used because it suggests the exact opposite of what I aim to show: namely, that the legal and economic conditions of sovereign debt issuance are indeed a wholly apolitical affair.

This paper therefore introduces and discusses three sets of terms, building upon one another to gradually expose the full extent of what is contained in supposedly minuscule technicalities on European primary and secondary sovereign debt markets. In the first section, I criticize what I call here the 'representational perspective' in which sovereign bond interest rates are set by markets in reaction to the economic soundness of sovereigns, i.e., to country fundamentals (debt-to-GDP ratio, inflation, productivity indexes, and so forth). I concur with the literature that certain phenomena on sovereign debt markets - particularly so-called 'flights' from one asset class to another - are not sufficiently explained by this representational 
notion. Neither do I agree that they constitute arbitrariness on the side of the creditors, however - as is sometimes argued (e.g., LiPuma and Lee 2004). Rather, I argue that a technicality is at work here. Sovereign debt works in two distinct ways: as a fiscal instrument for the debtor, and as an asset for the creditor. I argue that the latter requires markets to subject debtors to what I call the flow-stock conversion. As a fiscal instrument, sovereign bonds are issued as a promise to be repaid. As an asset, however, this repayment must be assumed to be guaranteed. Countries are therefore, when subject to market lending, operationalized by the demands of this lending in a precise technical form. They come to be shaped by the demands of debt repayment - not in an arbitrary form, but precisely along the lines imposed upon them by the asset function of their bonds. Countries are therefore converted into what I propose to call fundamentals.

In the second section, I continue the analysis by arguing that the power mechanism by which countries are converted into fundamentals is once again less arbitrary than critics assume. Its precise form is what I call a liquidity-solvency conversion, by which liquidity withdrawals from a certain asset class - sovereign bonds of specific countries or country groups - come to be converted to solvency problems. Mark Blyth is right, I maintain, in saying that the Eurozone crisis was not due to country spending, but liquidity withdrawals - yet, the precise form of these withdrawals indicates less arbitrariness and more technicality than he assumes (2015: 51-94). In the third section, I extend the implications of the concepts proposed here to the notion of crisis itself: the pre-2008 boom and post-2008 bust of European liquidity is neither a question of governmental excess, nor of market irrationality. I argue that it is rather due to a structural oscillation in the relation described here as country-fundamental conversion, and that this oscillation is not significantly explained within the crisis/normality paradigm. Fundamentals, as proposed here, are wholly internal to sovereign debt markets, which is to say that no aberration from normality - no crisis - can be discerned.

\section{Flow-Stock Conversion}

In this first section, I reconstruct the internal logic of sovereign bonds as an asset class, and observe their relation to sovereign debtors and creditors: the issuing country and its financiers. On the one hand, sovereign bonds are usually interpreted to be representational instruments: sovereign bond interest rates are set by markets in reaction to the country's economic fundamentals (Eaton 1993: 141). Thus, the present section examines the representational perspective of sovereign bonds. I show here, however, that this perspective is in fact the reverse of how sovereign bonds actually work. Sovereign bond issuance serves to finance government policies, 
whose economic effects in turn influence country fundamentals (ibid: 140-141). Moreover, " $[\mathrm{t}]$ he existing literature is unanimous in finding that spreads of euro area government bond markets reflect liquidity and credit risks, and are mainly driven by a common factor," an "international risk aversion." (Manganelli and Wolswijk 2009: 194) This means that market lending can be said to have an influence on country fundamentals, shedding doubt on the representational perspective.

First, markets lend expecting repayment, thus reducing policies to their fiscal impacts and thus to likelihoods of continued debt service prioritization. In the Eurozone in particular, it has been found that "credit markets (...) exert disciplinary pressure on governments with a shift [after EMU, S.E.] to debt-service ratio as the most relevant measure of creditworthiness." (Lo Conte 2009: 363; cf. Belke 2011) Second, market lending transposes actual or observed economic fundamentals to projected performances, inferring sovereign debt risk premia from these projections (Eaton 1993: 166-169; Eichengreen 2003: 87). Risk premia denote interest rate mark-ups relative to the interest rates demanded for a benchmark bond - in Europe, usually Germany's 10 year bond (Lo Conte 2009: 353). Finally, market lending influences fundamentals by rearranging governmental stakeholders, often turning government official's attention from one set of national or domestic stakeholders to another, or to an international level. Stiglitz (2010:36) characterizes the multitiered stakeholder structure of sovereign bonds as the decisive aspect in the match or mismatch between legal and political aspects of sovereign debt.

Uniting these perspectives is a prioritization of the asset function of sovereign debt (its role on creditor portfolios) over their fiscal function (financing the debtor's government). In the European context, the goal of the transposition of country policies to sovereign bond interest rates is for the bonds to perform as debt securities on banks' portfolios (Lo Conte 2009: 341-342). European sovereign debt securities are assets eligible to be held as tier 1 positions under Basel II regulations as incorporated in the European context by the European Capital Requirements Directives CRD III (up to 2013) and CRD IV. Such tier 1 capital ensures that a financial actor - in this case: a bank - can covering a sufficient amount of operative losses before requiring a bailout (Moseley 2013: 653). In a leveraged operation, a financial actor holds only a fraction of the capital advanced - by a factor called 'leverage ratio' and specifically defined by the European Banking Authority (BIS 2013) - while borrowing the remainder from other financial actors. Since repayment of the latter funds depends on the outcome of the investment, only the former is safe in case of a market downturn. Assets belonging to the tier 1 capital category therefore have to be particularly safe to guarantee the basic existence and well-being of the financial actor. Designating them as tier 1 capital therefore means, from a 
regulatory perspective, that any sovereign bond held by a bank is eligible to be used as collateral in a leveraging operation (cf. Epstein and Habbard 2013: 330).

However, this function depends on a crucial presupposition: sovereign bonds, which in reality are a flow of payments from the debtor country to its creditors, to be considered a stock. This is a temporal transposition. Sovereign bond purchases by creditors depend on "the extent that government default is anticipated." (Guerreri et al. 2012: 188) By virtue of this anticipation, the flow of sovereign debt repayments is converted to a stock for the purposes of sovereign debt as an asset. This flow-stock conversion converts actual into projected payment flows. The expectation by which sovereign bonds can perform their role as stable assets - as tier 1 capital - is that repayment by their issuer, the debtor country, is guaranteed. This seems reasonable since the issuer is a sovereign entity (Eaton 1993: 140). The sovereignty of the debtor allows investors to expect it to exercise its coercive powers to tax or, at least, to invoke its credit ratings to borrow internally (Mundell 1996: 77, 110; Panizza 2010: 91-107). For this reason, sovereign bonds can serve as tier 1 assets: it is reasonable to assume their stock function to be fulfilled at all times.

By the same token, however, repayment depends to a certain extent on the willingness of country officials to prioritize debt servicing - or even to repay debt at all (Eaton 1993: 166). Indeed, one of the aspects of sovereign borrowing most often discussed in the literature is that, for lack of enforcement mechanisms, a sovereign default is always just one politician's moral hazard away (Eichengreen 2003: 93; Panizza et al. 2009: 659). To maintain the flow-stock conversion, then, it is necessary to ensure debt service prioritization. For example, in its second adjustment programme for Greece in 2012, the European Commission stated it "welcomes the intention of the Greek authorities to introduce over the next two months in the Greek legal framework a provision ensuring that priority is granted to debt servicing payments." (European Commission 2012: 6) At other, perhaps more 'normal' times, debt service prioritization is ensured by the threat of cutting the country off capital market access (Eaton 1993: 151-152; Eichengreen 2003: 78-79).

This illustrates that the assumption that sovereign bond interest rates represent the performances and policies of their issuing governments is necessary, however risky its foundations. It allows the flow-stock conversion which in turn allows the use of sovereign bonds as debt securities. It is only because this asset class is issued by a sovereign entity that markets can assume this sovereignty to be exercised to guarantee debt repayment, allowing the projection of this payment flow as a stock. Yet, this means that the country's sovereignty is structured by an operationalization of the country by creditors. These transpose government policies 
onto a different level - changing the stakeholder structure, changing the assessment criteria, changing the benchmark. They introduce phenomena irreconcilable with mere representation. Such phenomena include financial spillovers (Guerreri et al. 2012: 185), influences of "perceived overall financial risk" (Botta 2013: 423), as well as "market sentiment" in interest rate setting (Lo Conte 2009: 344). All of these support the hypothesis of a prioritization of the asset function of sovereign bonds creditor interest - over their fiscal function - debtor interest.

A brief survey of the literature vindicates the hypothesis. Any country can be subject to demands backed up or possibly enforced by the ever-present possibility of capital flight, i.e., the withdrawal of funds (Eaton 1993: 149; Wolf 2002: 38-52). Backed by this pressure, creditors can demand risk premia (Lo Conte 2009: 346). Markets can also monitor the debtor country's policies with regard to the likelihood of successful debt servicing (Eaton 1993: 164; Eichengreen 2003: 76). Moreover, creditors have opportunities to hedge against risk - in the case of debt repayments, futures are particularly relevant (Lo Conte 2009: 347). Outside of Europe, this is further reinforced by the denomination of sovereign bonds which, independent of the country of issuance, are usually denominated in U.S. dollars - which poses additional conversion risks and current account pressures for governments servicing their debt, but makes investment and allocation of debt securities easier for international portfolios (ibid: 343). In European sovereign bond markets, the common denomination of debt securities in Euros has the same effect on Southern European countries, as will be discussed below (Lane 2006: 53; Belke 2011: 685; Coeuré 2013). At times, as seen above, this is formally reinforced (European Commission 2012: 6).

Thus, the conversion from sovereign bond repayment flows to their projected guarantee certainly benefits the creditors (Stiglitz 2010: 35-69). The terms by which a sovereign bond is transposed to its asset or stock function are not set by the country issuing the bonds. Neither, however, are they arbitrarily set by creditors. They are a technicality: a transposition of actual to projected performances, expectations, and intertemporal optimization problems (Panizza et al. 2009: 680). Their precise terms - and hence their precise effects - must be examined in more detail.

\section{Fundamental and Liquidity-Solvency Conversion}

A closer reading of the flow-stock conversion yields further insights into its more hidden, seemingly mundane and technical effects. To uphold the idea of a representation of a country's policies and economic growth by sovereign bond interest rates is crucial to the flow-stock conversion, as seen above. More is at stake, 
however: namely the effect of sovereign debt technicalities on the sovereignty of countries issuing sovereign bonds. In the flow-stock conversion discussed above, the sovereignty of the debtor country is harnessed as a payment guarantee. Thus, when it issues sovereign debt, a country is thus no longer a sovereign country endowed with the ability to renege on payments and ultimately to default (independent of the consequences of that decision). The priority of the country-market relation is reversed: markets have power as creditors, while a sovereign debtor country becomes the fundamental of sovereign bonds. I propose to conceptualize this as a fundamental, containing both aspects of the flow-stock conversion, as opposed to the notion of country fundamentals.

In the representational perspective, country fundamentals are measurements of actual and projected performances of of the economy of the debtor country. These economic measurements - mathematical formulae comprised of coefficients indicating GDP per capita, current account balance, debt relative to GDP, the composition of debt, and future forecasts based on inflation coefficients - indicate the fiscal well-being of the debtor country and hence its riskiness as an investment: its projected ability to repay debt (Panizza et al. 2009: 685 Fn 50). In the stronger sense proposed here, however, fundamentals are more than mathematical formulae. Rather, these formulae have effects upon the country: it comes to be operationalized by its creditors in order to repay its debts. Thus, the mathematical tools ostensibly assessing country fundamentals for interest rate adjustments are in reality effects splitting and transposing the country.

The fundamental restructures its corresponding country to prioritize debt servicing. In turn, this imposes restructuring upon the country. Even when no Troika is involved as in the Greek or Irish cases, the fundamental reorganizes the country to focus on improving specific economic indicators: its growth vis-à-vis its debt/GDP ratio; its socio-economic trajectories such as technological and educational progress vis-à-vis inflation. It does so by subjecting the country to benchmarking - in the European case, benchmarking against Germany (Holman 2004: 715; Manganelli and Wolswijk 2009: 215-216; Pusch 2012: 6). The seemingly arcane technicality of how country fundamentals in the classical sense are assessed thus becomes vitally important politically since its terms are at once the benchmarking targets imposed upon the debtor country through its fundamental.

What the debtor country can do with the funds derived from the fiscal function of debt issuance is thus closely monitored and influenced by its creditors. In an orthodox perspective, close monitoring is necessary since elected officials tend not to prioritize debt servicing (Eaton 1993: 159-160; Mundell 1996: 115). 
From a critical perspective, such 'close monitoring' is often performed violently, either by outright imposition (as seen above for the Greek case), or by the gyrations of international capital markets (Strange 1998; LiPuma and Lee 2004). This paper takes a middle position: I propose to examine the mechanism behind this using the term liquidity-solvency conversion.

To illustrate this, one must consider the concept of 'contagion' on primary sovereign bond markets. If the sovereign bond interest rate merely reacted to country fundamentals and their sustenance or depletion by more or less rational elected officials, as the representational perspective claims, contagion between sovereign bonds would be impossible. The fundamentals of one country could not have a direct effect on those of another. Even if they are subject to simultaneous macroeconomic shocks, the interest rates of the countries' sovereign bonds would ex hypothesi move in the same direction, independently. Only when a financial shock occurs in both countries, interest rate co-movement occurs - yet this co-movement has no relation to fundamentals (Manganelli and Wolswijk 2009: 193-194; Guerreri et al. 2012: 184).

Such co-movements in the Eurozone are indeed causally related, as capital moves from riskier Southern European sovereign bonds to less risky German and U.S. bonds (Shambaugh 2012: 216). Prior to 2009, European peripheral current account deficits rose continually (Lane 2006: 53). In the crisis, however, the volume of cross-country financial account movements into GIPSI countries in particular markedly deteriorated, leading to rising interest rates (Nowak 2012: 6). Attributing this to individual country fundamentals assessed by market movements is certainly possible. In the Greek case, this development is due to a steep decline in the servicerelated balance of payments, dropping by 21 per cent from 2007 to 2008 - largely a result of the extreme focus of the Greek economy on tourism (Visvizi 2012: 18). However, financial account movements were similar for all peripheral European countries (Lo Conte 2009: 344; Pusch 2012: 2). This indicates a common origin in the 'market sentiment' mentioned above.

Yet, 'market sentiment' as an analytical category misses substantial aspects of the effects in question since it is an insufficiently precise description of what I propose to call liquidity-solvency conversion: a pattern of lending withdrawals forcing country fundamentals into specific cross-country benchmarking, resulting in risk premia co-movements (Belke 2011: 678). These co-movements were independent of the actual macroeconomic differences of European peripheral countries. They crossed different types of booms and busts (Ireland's banking sector, Portugal's public debt, and Cyprus's financial sector have little in common), different types of 
distress (Spain's pre-2008 credit overextension was mainly private, Greece's mainly public), and different sizes of economies (Italy and Greece being on the extreme ends of this spectrum). What occurred was a liquidity shortage on sovereign debt markets which I maintain was turned into a solvency problem for the countries exposed to it as they attempt to roll over debt. An example is the case of Italy in 2011 (Shambaugh 2012: 169). The Italian government had not been regarded as insolvent prior to 2011 (Belke 2011: 685; Bastasin 2012: 288). That summer, however, markets inferred a possible insolvency from the refinancing difficulties Greece and Portugal, Ireland and Spain were facing, and withdrew their liquidity - thus imposing upon Italy the very insolvency they feared to take place (Bastasin 2012: 287).

I maintain, however, that this liquidity-solvency conversion did not just occur in this one case. Its effects are more far-reaching. Through it, markets gain the power to restructure debtor countries along the operational lines of their corresponding fundamental. This, in turn, means that the precise technical features of each respective fundamental have precisely discernible effects upon their corresponding countries. Through their fundamental, country governments are operationalized as actors whose primary duty is to prevent default, to service debt and to instill market confidence that it will continue doing so over the bond's maturity range. Market judgment on anticipated debt servicing constitutes a lending threshold, as markets only lend to governments from whom they expect repayment. The means by which governments repay old debt, however, stem to substantial extents from market lending. Above a certain debt-to-GDP ratio, taxation would not even theoretically suffice to repay all sovereign debt. Thus, debt servicing depends substantially on the ability of debt roll-over - which is to say that a liquidity withdrawal reduces a government's ability to repay old debt, putting it into arrears which lead to a further liquidity withdrawal, and so forth (Shambaugh 2012: 179). Market anticipation of debt servicing thus determines the extent to which actual debt servicing can be provided.

It is crucial to examine what this entails for the concept of the fundamental - and hence the pressures a country faces when operationalized as such. Based on the structural analysis offered above, a fundamental can now be identified as a selfreferential structure which is entirely internal to markets. Lending to countries relies on the assessment of a fundamental as sound, i.e., the credibility of a credible commitment to uphold fiscal solvency. This, in turn, presupposes debt roll-over ability, i.e., market liquidity. A country's solvency - i.e., its fundamental's ability to maintain fiscal soundness - relies on market liquidity, an exogenous variable the country has no control. It relies on financial market conditions: expansion or contraction, boom or bust insofar as investment behavior is concerned; contagious 
dynamics on bond markets. Market actors' claims to assess country fundamentals really mean to say that they assess liquidity conditions: they assess themselves.

The Eurozone crisis exemplifies this. Here, sovereign bond market liquidity is transnationally integrated since currency risk is removed in European Monetary Union (EMU) (Schüler 2002; Lo Conte 2009: 347; Manganelli and Wolswijk: 215-216). This leads to the indiscriminate portfolio movements discussed above - 'market sentiment' or 'panic' (De Grauwe and Ji 2013). For example, in times of pre-2008 'yield panic' (Hau and Thum 2009: 716), lending to GIPSI countries was considered to be within reasonable risk parameters. After 2009, market distrust radiated outward from Greece to other GIPSI countries and beyond, without much consideration of the specifics of the country in question.

By contrast, the solvency of a government remains its national fiscal responsibility (Lane 2012: 49-50; cf. Holman 2004: 728). As explained above, this has its origin not in national sovereignty per se, but rather in the technical feature of sovereign bond issuance discussed above as flow-stock conversion: the country's sovereignty is harnessed as a repayment guarantee. Market imposition of the fundamental therefore makes the country responsible not only for debt servicing, but also for restructuring its economy to sustain good fundamentals. In addition, as seen in this section, a global liquidity crunch brings a country's debt roll-over capabilities under distress, threatening the most important aspect of fundamentals (the debt-to-GDP ratio) by removing the funds necessary to service debts and by shrinking GDP. By virtue of the liquidity-solvency conversion, this is then interpreted by markets as a sign of domestic and fiscal distress (Strange 1998; Wolf 2002: 38-52; Schiaffino 2013: 457-462).

\section{Intra-Market Hedges and Extra-Market Hedges}

Yet more escalations are contained in the ripple effects of seemingly minuscule and benign sovereign debt technicalities. A third layer of conversions is added to the country-fundamental transposition at this point. Reinforcing the flow-stock conversion and its concomitant liquidity-solvency conversion, this third layer determines the exact extent of pressures to which a country is subject when it becomes a fundamental - and the concomitant pressures upon financial actors lending to the debtor country. The Eurozone crisis is illustrative here: often described as a sovereign bond crisis, it is really an interbank market crisis imposed upon countries via the liquidity-solvency conversion which also - an aspect often neglected in the critical literature - cyclically exacerbates the banking crisis. 
The description of the Eurozone crisis begins on bank portfolios. European banks hold sovereign bonds as tier 1 capital. Of their total assets in 2009Q4, 16 per cent were government debt securities (Lucarelli 2011: 208). This results in the vulnerabilities discussed above: if European governments are unable (or unwilling) to repay their debts, these assets are terminated, and the European banking system is unable to continue lending - in the worst scenario, banks may not even continue to exist (Shambaugh 2012: 159). By no means was that a remote possibility: at the height of the Greek phase of the crisis, in June 2010, European banks were exposed to more than 200 billion Euros in Greek debt securities (Lucarelli 2011: 208). Certainly, in a conventional perspective, this makes governmental behavior a source of danger for bank portfolios: the country's extra-market sovereignty (ability to renege on payments) continues to haunt the fundamental's intra-market sovereignty (guarantee of debt repayment).

For legal reasons, this came to be particularly relevant in the Eurozone crisis. As stated above, the European Capital Requirements Directive in effect during the Eurozone crisis (CRD III) designates sovereign bonds eligible to be tier 1 capital assets without restrictions (EU Regulation 575/2013, Art. 214, Sect. 2[a]). Thus, when the European public - and its global counterparts - demanded large banking institutions to deleverage after the 2007/2008 crisis, European banks ironically came to be exposed to sovereign risk (Barroso and Van Rompuy 2011; EBA 2011). The extent of this deleveraging process was significant. Throughout Europe, the ratio of bank loans to bank deposits went down significantly, from 138 per cent to 126 per cent according to ECB figures - a "steady decline" which "points to a corresponding substantial reduction in the banking sector leverage." (ECB 2013) Across the European banking system as a whole, tier 1 capital ratios have increased from 8 per cent in 2008 to 12 per cent in 2012 (Lawton 2013).

This also increased the vulnerability of European banks to the sovereign assets they held (Isidore 2012). By the same token, countries came to be embedded into the dynamics of a European banking crisis through their fundamental - the demands of the flow-stock conversion given force by the liquidity-solvency conversion (Blyth 2015: 73). To explain the extent of this, a second function of countries with regard to their sovereign debt must be explored.

Countries are fundamentals, thus serving their function to stabilize banks' portfolios as tier 1 capital assets. Sovereign bonds are not the only means to stabilize banks' portfolios, however; the same stabilizing function can be performed by the credible commitment of sovereigns to bailouts: recapitalizations and asset relief. In both ways, the fundamental performs a hedging function for its banking system. Moreover, it is made to remain under market supervision while fulfilling its duty 
to recapitalize or bail out banks by the liquidity-solvency conversion. Thus, in the post-2008 bailouts of European banks, governments issued debt securities to raise money for bailing out their banks. This was subsequently operationalized by these very banks as an increase in sovereign debt loads, leading to lending withdrawals, and so forth (Lucarelli 2011:209). Once again, however, wholesale critiques of these practices (particularly those critiques invoking 'greed') neglect crucial details whose analysis uncovers the precise way in which these effect come to play out.

Countries serve as fundamentals in two ways - portfolio stabilization through debt security issuance, as well as bailouts: recapitalization and asset relief. The fundamental thus reconstitutes the country as a double market entity: as an intra-market hedge in the former sense (stabilizing portfolios by issuing tier 1 capital); as an extra-market hedge in the latter sense (bailing out banks). To serve as intra-market hedges, as discussed above, countries have to fulfill the economic demands of creditors such that the flow-stock conversion can occur. Thus, countries have to be 'fiscally sound' in order to serve as fundamentals. Yet, what soundness of fundamentals denotes is decided by the creditors. Their decisions are enforced by the liquidity-solvency conversion, by which European banks (in this case) have the power to withdraw liquidity and blame the resulting fiscal shortage on governmental insolvency.

Countries are therefore embedded into market dynamics in a special sense. Their double position as market entities (intra-market hedges) and yet as guarantors of market structure as a whole (extra-market hedges) is set according to market dynamics. Here, the relation between country, fundamental, and sovereign debt is subject to the notion of crisis. As extra-market hedges, countries have an obligation to bail out banks (Acharya and Steffen 2013). However, the terms of this obligation are set by the banking system and are caught up in the self-referential nature of the fundamental discussed above, since countries derive the funds to bail out banks from market liquidity - i.e., from banks (Botta 2013: 427). Thus, the bailout is subject to contradictory conditions set by the financial institutions it rescues.

First, while straining its finances because it bails out banks, the country must also remain fiscally sound because it remains benchmarked by financial institutions on the level of the flow-stock conversion. It must maintain "counterinflationary credibility." (Wolf 2002: 44) That is, the country must attempt to issue debt - incurred to save banks - at interest rates set by banks. For these to be at low levels, however, the country must maintain a low debt-to-GDP ratio (ibid: 43; Botta 2013: 427-428). In lieu of suddenly expanding its GDP, the country's ability to remain 'sound' will therefore be influenced by the amount of debt it has to service. This leads to a selfreferentiality of bailouts: a direct result of the self-referentiality of the fundamental 
as a market entity. When it is said that countries bail out banks, this really means that countries tap into market funding to disburse it to banks. This is triply convenient for creditors. The debt issued by governments serves them as intra-market hedge (as tier 1 asset). Secondly, the conditions of issuance (the fundamentals in question as well as interest rates) are set by them. Thirdly, the bailout serves as extra-market hedge (Acharya and Steffen 2013).

In the country's responsibility to fulfill its role as intra- and extra-market hedge, the size of its commitments is the independent variable vis-à-vis the country's ability to fulfill its responsibility. The lengths to which this can go can be seen in the bank bailouts immediately prior to the Eurozone crisis. Here, this is particularly evident, as these bailouts showed a clear size mismatch. European banks' portfolio sizes often exceed the total fiscal capabilities of their corresponding countries. Not only was the total asset size of the European banking system three times as large as the European real economy in 2007 as well as 2013 (Shambaugh 2012: 162; Lawton 2013); the largest European banks are also often bigger than the entire GDP of their home country - let alone fiscal capability. The Dutch ING group, German Hypo Real Estate or Portugal's Espirito Santo group are examples of this (Hau and Thum 2008; Goncalves 2014). The Dexia group, for example, whose activities extended far beyond Europe, particularly into U.S. subprime markets, had to be recapitalized in 2008 and 2011 by Belgium, the Netherlands, and Luxembourg together, because its size exceeded any of the three countries' capabilities (Guillén 2012: 50; Acharya and Steffen 2013).

This size mismatch allows a conclusion about the nature of the European debt crisis. What presents itself as a 'crisis' of government solvency is really a crisis of liquidity converted into one of solvency. It is neither the result of market irrationality nor of governmental overborrowing. Nor was the European crisis caused by investor irrationality. Such irrationality presupposes the possibility of rational (or irrational) market assessment of preexisting country fundamentals to gauge the rationality or irrationality of the investment (Lux 1995). Such preexisting fundamentals, however, do not exist, as I have shown earlier. They are in reality a self-referential market projection serving as a transmission belt for market demands onto countries. Markets may thus well be irrational - but it is not possible to establish when they are and which aspects of self-referential liquidity are the result of such irrationality. Likewise, the crisis cannot be a question of governmental overborrowing prior to 2008. This would require that the representational theory holds - that government solvency is the independent variable of of country fundamentals and hence investments - which I have shown here not to be the case.

Combining these findings finally allows a hypothesis regarding the nature of 
crisis. If, as shown here, market investments are ultimately self-referential, neither the pre-2008 expansion shock nor the post-2008 contraction shock in the Eurozone can be an aberration from normal mechanisms since these are much contained in the overall self-referentiality of the market structure at hand. This is to say that neither of them can be 'crisis' conditions. They cannot be a result of state moral hazard because fundamentals preceding market conditions do not exist. By the same token, they cannot be a result of market moral hazard since the object of market investment are not a country's fundamentals - but the country operationalized as a fundamental, i.e., as caught up in market self-referentiality. That the country is thus structured by the fundamental means that the country cannot be the measuring rod of the fundamental's oscillations - and hence that sovereign bond interest rates cannot be measured against anything given. There is no standard, hence there is no aberration; there is thus no normality and hence no crisis.

\section{Conclusion}

I have argued here that the origin of the Eurozone crisis lies neither in unsustainable public and private borrowing of European peripheral countries prior to 2009, as some argue, nor in the unreasonable and/or arbitrary demands of their creditor, as others have maintained. Rather, its origin can be found in the effects of minuscule and seemingly arcane technicalities to which sovereign debt issuance is subject. To show this, I have proposed a set of terms which, I maintain, are better equipped to analyze the effects of these minuscule technicalities as other, more common terms are. I have proposed to replace the notion of country fundamentals (plural) with that of a fundamental (singular) to show that a country is not subject to market assessment of its independent policies when it is being lent to, but rather subject to market lending pressures forcing it to adopt certain policies even in the absence of outright imposition. To better describe the precise nature of market pressures in this case, I have proposed the notions of flow-stock conversion and liquidity-solvency conversion. The former allows the conversion of sovereign debt as a fiscal instrument to sovereign debt as an asset, thus embedding it (and its corresponding country) into sovereign debt market dynamics. These, in turn, play out as pressure upon the country through the liquidity-solvency conversion turning portfolio restructurings into fiscal solvency shortages. Finally, I have proposed the notion of countries as intra-market hedges and extra-market hedges to illustrate the precise extent of market pressures upon countries: to recapitalize banks, countries need to issue more debt at market interest rates, doubling down on the pressure from the liquidity-solvency conversion.

The conclusion of this paper is that countries come to be inscribed into market dynamics over which they have no control - and moreover, that these market 
dynamics are wholly self-referential. How generalizable beyond the Eurozone crisis is this finding? At minimum, it seems that the concepts propose here allow a more precise account of 'crises' outside of the Eurozone if similar regulatory conditions obtain. In particular, it appears that the twofold function of sovereign bonds as fiscal and portfolio instruments is universal, and that international financial actors often use sovereign bonds as tier 1 capital (Guerreri et al. 2012: 182). An example for a more general use of the concepts proposed here could be a more dynamic notion of counterinflationary credibility. As the fundamental oscillates, and with it the country's fiscal capacities, the incentive structure of political actors oscillates as well. In times of liquidity boom, a far broader amount and range of expenses are within what is credible as commitments to low inflation. Without the crisis hypothesis, it is not irrational, nor morally hazardous, to use this fiscal space. Conversely, neither is the deployment of fiscal restrictions by markets under conditions of liquidity shortage. At a minimum, a dynamic view thus entails the abandonment of the notion of 'crises' of sovereign debt, and possibly of financial 'crisis conditions' in general - insofar as what has been shown here is likely to apply for other real economic fundamentals of other classes of assets as well.

\section{References}

Acharya, Viral and Sascha Steffen. 2013. The 'Greatest' Carry Trade Ever? Understanding Eurozone Bank Risks. Working Paper, NYU Stern School of Business.

Barroso, José Manuel and Herman Van Rompuy. 2011. Joint letter of European Commission President José Manuel Barroso and European Council President Herman Van Rompuy to their G20 partners ahead of the G20 Summit in Cannes (France), 3-4 November 2011. Press Release, European Commission MEMO/11/750. Accessed at http://europa.eu/rapid/pressrelease_MEMO-11-750_en.htm?locale=en on 17 August 2014.

Bastasin, Carlo. 2012. Saving Europe. How National Politics Nearly Destroyed the Euro. Washington, DC: Brookings Press.

Belke, Ansgar. 2011. The Euro Area Crisis Management Framework: Consequences for Convergence and Institutional Follow-ups. Journal of Economic Integration, 26 (4), pp. 672-704.

Blyth, Mark. 2015. Austerity. The History of a Dangerous Idea. Oxford: Oxford University Press.

Botta, Alberto. 2013. Fiscal policy, Eurobonds, and economic recovery: heterodox policy recipes against financial instability and sovereign debt crisis. Journal of Post Keynesian Economics, 35 (3), pp. 417-441.

Coeuré, Benoît. 2013. Outright Monetary Transactions, one year on. Speech at the conference "The ECB and its OMT programme," 2 September 2013. Accessed at http://www.ecb.europa.eu/ press/key/date/2013/html/sp130902.en.html on 10 July 2014. 


\section{S. Engel}

Eaton, Jonathan. 1993. Sovereign Debt: A Primer. The World Bank Economic Review, 7 (2), pp. 137-172.

EBA. 2011. Results of the 2011 EU-wide stress test. Press Release, 15 July 2011. Accessed at http://www.eba.europa.eu/documents/10180/15935/2011+EU-wide+stress+test+results++press+release+-+FINAL.pdf/b8211d3b-562e-40d4-80f8-0b5736c20345 on 17 August 2014.

ECB. 2013. Banking Structures Report, November 2013. Accessed at http://www.ecb.europa.eu/pub/ pdf/other/bankingstructuresreport201311en.pdf on 10 July 2014.

Eichengreen, Barry. 2003. Restructuring Sovereign Debt. Journal of Economic Perspectives, 17 (4), pp. 75-98.

Guerreri, Luca, Matteo Iacoviello and Raoul Minetti. 2012. Banks, Sovereign Debt, and the International Transmission of Business Cycles. NBER International Seminar of Macroeconomics, 9 (1), pp. 181-213.

Guillén, Arturo. 2012. Europe: The Crisis Within a Crisis. International Journal of Political Economy, 41 (3), pp. 41-68.

Hau, Harald and Marcel Thum. 2009. Subprime crisis and board (in-) competence: private versus public banks in Germany. Economic Policy, 24 (60), pp. 701-752.

Holman, Otto. 2004. Asymmetrical regulation and multidimensional governance in the European Union. Review of International Political Economy, 11 (4), pp. 714-735.

Isidore, Chris. 2012. S\&P downgrades BNP Paribas, 2 other French banks. CNN Money online, 25 October 2012. Accessed at http://money.cnn.com/2012/10/25/investing/french-banksdowngrade/ on 18 August 2014.

Lane, Philip. 2006. The Real Effects of European Monetary Union. Journal of Economic Perspectives, 20 (4), pp. 47-66.

Lane, Philip. 2012. The European Sovereign Debt Crisis. Journal of Economic Perspectives, 26 (3), pp. 49-68.

Lawton, Christopher. 2013. Euro-Zone Banking Assets Reach \$39.86 Trillion. The Wall Street Journal online, 4 November 2013. Accessed at http://online.wsj.com/news/articles/SB1000142405 2702303936904579177412896271796 on 18 August 2014.

LiPuma, Edward and Benjamin Lee. 2004. Financial Derivatives and the Globalization of Risk. New York: Public Planet Books.

Lo Conte, Riccardo. 2009. Government Bond Yield Spreads: A Survey. Giornale degli Economisti e Annali di Economia, 68 (3), pp. 341-369.

Lucarelli, Bill. 2011. German neomercantilism and the European sovereign debt crisis. Journal of Post Keynesian Economics, 34 (2), pp. 205-224.

Manganelli, Simone and Guido Wolswijk. 2009. What drives spreads in the euro area government bond market? Economic Policy, 24 (58), pp. 191-240.

Mundell, Robert. 1996. Debt and Deficits in Alternative Macroeconomic Models. In: Mario 
Baldassari, Robert Mundell and John McCallum (Eds.): Debt, Deficit, and Economic Performance. New York: St. Martin's Press, pp. 5-130.

Nowak, Olaf. 2012. EU and Member States' balance of payments during the economic turmoil. Eurostat Statistics in Focus, No. 32/2012. Accessed at http://epp.eurostat.ec.europa.eu/ cache/ITY_OFFPUB/ KS-SF-12-032/EN/KS-SF-12-032-EN.PDF on 17 August 2014.

Panizza, Ugo, Federico Sturzenegger and Jeromin Zettelmeyer. 2009. The Economics and Law of Sovereign Debt and Default. Journal of Economic Literature, 47 (3), pp. 651-698.

Panizza, Ugo. 2010. Is Domestic Debt the Answer to Debt Crises. In: Barry Herman, José Ocampo and Shari Spiegel (Eds.): Overcoming Developing Country Debt Crises. Oxford: Oxford University Press, pp. 91-107.

Pusch, Toralf. 2012. The Role of Uncertainty in the Euro Crisis - A Reconsideration of Liquidity Preference Theory. Discussion Paper, Zentrum für Ökonomische und Soziologische Studien, Universität Hamburg.

Schiaffino, Pablo. 2013. A comment on the European Central Bank solution vs. the Keynes solution. Journal of Post Keynesian Economics, 35 (3), pp. 457-462.

Shambaugh, Jay. 2012. The Euro's Three Crises. Brookings Papers on Economic Activity, 2012 (1), pp. 157-231.

Stiglitz, Joseph. 2010. Sovereign Debt: Notes on Theoretical Frameworks and Policy Analyses. In: Barry Herman, José Ocampo and Shari Spiegel (Eds.): Overcoming Developing Country Debt Crises. Oxford: Oxford University Press, pp. 35-69.

Strange, Susan. 1998. Mad Money. Minneapolis: University of Michigan Press.

Visvizi, Anna. 2012. The Crisis in Greece and the EU-IMF Rescue Package: Determinants and Pitfalls. Acta Oeconomica, 62 (1), pp. 15-39.

Wolf, Martin. 2002. Exchange Rates in a World of Capital Mobility. Annals of the American Academy of Political and Social Science, 579, pp. 38-52. 